\title{
Role of Copper, Magnesium, and Zinc in Pathogenesis of Hepatocellular Carcinoma and Cirrhosis
}

\author{
Afaf M. Attia ${ }^{1}$, Sohayla M. Attalla ${ }^{1}$, Enase A.M.E Baraka ${ }^{2}$, Maysaa El Sayed Zaki ${ }^{3}$, \\ Nashwa Y. Elkhouly 4
}

\begin{abstract}
KEYWORDS

Trace elements,

Hepatocellular carcinoma,

Cirrhosis,

Copper,

Zinc,

Magnesium

The present study aimed to estimate the level of copper, magnesium and zinc in patients of cirrhosis and hepatocellular carcinoma (HCC) to determine their correlation to pathogenesis of these diseases. A case-control study was conducted on thirty subjects that were included as control (group) I obtained from blood transfusion donners' healthy subjects. All patients whose coming to the specialized medical hospital Mansoura University from January 2016 till January 2017 were clinically evaluated and investigated to select 70 subjects that were classified into two groups: twenty-five patients with cirrhosis (group II), and forty-five patients with hepatocellular carcinoma (group III). The levels of copper, magnesium and zinc were assessed in the blood of the three groups. Copper level showed significantly increased values while magnesium and zinc were significantly decreased comparing to control group in both cirrhosis and HCC groups separately. There were significant increase in zinc level and significant decrease in magnesium and copper levels in comparison between HCC and cirrhotic groups. Also, a significant negative correlation between zinc and magnesium levels and the advances in liver condition, advances in spleen condition and presence of ascites was observed, while there is non-significant negative correlation between Child-Pugh classification and the levels of zinc and magnesium in cirrhosis and HCC groups. As regards copper level, there was a significant positive correlation between the copper level and the advances in liver condition, advances in spleen condition presence of ascites and Child-Pugh classification. In conclusion, there is association between copper, magnesium and zinc and the severity of the cirrhosis and HCC.
\end{abstract}

\section{Introduction}

Metabolism of trace metals occurs in the liver and their levels indeed changed with variable causes of liver disease (Qasim et al.,

\footnotetext{
$\overline{{ }^{(I)} \text { Forensic Medicine and Clinical Toxicology }}$ Department, Faculty of Medicine, Mansoura University - Egypt

${ }^{(2)}$ Internal Medicine and Gastroenterology Department, Mansoura University, Egypt, Taibah University, KSA

${ }^{(3)}$ Clinical Pathology, Faculty of Medicine Department, Mansoura University - Egypt

${ }^{(4)}$ Internal Medicine Department, Al-Azhar University, Egypt, Taibah University, KSA.
}

2010). Copper $(\mathrm{Cu})$ acts as a cofactor of hepatic fibrosis in chronic liver diseases so the sickness advances from endless hepatitis to liver cirrhosis in relationship with expanded $\mathrm{Cu}$ levels in biological fluids (Chen and Teo, 2001). It was anticipated that the elevated copper level can harm the liver parenchyma via lipid peroxidation that leads to dysfunction in the cell membrane, decreased fluidity, inactivation of enzymes and changes ion permeability (Mengand Zhang, 2006; Arain et al., 2013).

Zinc protects against carcinogenesis as it is also help activation of DNA repair enzymes. 
Also it is a component of superoxide dismutase (SOD), an enzyme that removes free radicals (Hiroyuki et al., 2004). Liver is the main organ responsible for the zinc metabolism, and various liver diseases may be influenced by zinc deficiency (Grüngreiff and Reinhold, 2011).

There are little studies on magnesium $(\mathrm{Mg})$ status in patients with cirrhosis (Meir Medical Center, 2013). Several reports have shown that serum manganese-dependent superoxide dismutase (MnSOD) levels in patients with hepatitis virus $\mathrm{C}(\mathrm{HCV})$-related chronic liver diseases are associated with various clinical findings, such as fibrosis and hepatic oxidative stress. However, the significance of serum MnSOD levels has not been fully examined in patients with hepatocellular carcinoma (HCC) (Clemente et al., 2007; Nahon et al., 2007). The present study aimed to estimate the level of copper, magnesium and zinc in patients of cirrhosis and hepatocellular carcinoma (HCC) to determine their correlation to pathogenesis of these diseases.

\section{Subjects and Methods}

\section{Sample size calculation:}

At a level of $95 \%$ confidence level and power of the study 80 , the research team assumes that, the effect of copper in occurrence of hepatocellular carcinoma was 0.5 medium. The minimum sample size for each group is 25 subjects.

https://www.anzmtg.org/stats/PowerCalculator/ PowerTtest.

\section{Subjects:}

A case-control study was conducted on thirty subjects that were included as control (group) I (matched age and sex) obtained from blood transfusion donners' healthy subjects. All patients whose coming to the specialized medical hospital Mansoura University from January 2016 till January 2017 were clinically evaluated and investigated to select 70 subjects that were classified into two groups: twentyfive patients with cirrhosis (group II), and forty-five patients with hepatocellular carcinoma (group III).

The diagnosis of liver cirrhosis and HCC based on clinical features, laboratory tests (liver function and alpha fetoprotein), and abdominal ultrasound. The Child-Pugh score used to assess the severity of liver cirrhosis. According to Cholongitas et al. (2005), the Child-Pugh system looks at the following 5 things that tell how well the liver is working: bilirubin levels, albumin levels, prothrombin time, presence of ascites and presence of encephalopathy. Each one is given a number score, and based on that score, people fall into 1 of 3 classes: class A means the liver is working normally, class B means mild to moderate illness and class $\mathrm{C}$ means there is severe liver damage.

Patients with cirrhosis or/and hepatocellular carcinoma associated with other etiologies such as alcoholic or congenital disorders were excluded from the study.

The levels of copper, magnesium and zinc were assessed in the blood of the three groups.

\section{Methods}

From each subject $10 \mathrm{ml}$ blood were collected, separated to two aliquots and transported to the laboratory. Sera were separated and one aliquot was used for liver function tests including alanine aminotransferase (ALT), aspartate aminotransferase (AST), albumin and total bilirubin by autoanalyzer (Dialab 450 system) and alphafetoprotein (AFP) measurement by 
enzyme linked immunosorbent assay (ELISA DRG). Sera separated from the second blood aliquot were stored at $-20^{\circ} \mathrm{C}$ for further analysis of zinc, copper and magnesium by colorimetric methods using spectrophotometre. Magnesium (expressed in $\mathrm{mg} / \mathrm{dl}$ ) was measured according to Khayam-Bashiet al. (1977), copper and zinc (expressed in $\mu \mathrm{g} / \mathrm{dl}$ ) were measured spectrophotometrically according to Abe et al. (1989). All the kits were supplied by Crest Biosystems (Gitanjali, Tulip, India).

\section{Statistical analysis}

All statistical analyses were performed using SPSS 16.0 (Chicago, IL) and a significance threshold of $p<0.05$ was used.
Continuous data was expressed as mean $\pm \mathrm{SD}$ and compared between groups using Student's $t$ test. Categorical data was analyzed using a two-sided Chi-squared test when indicated.

\section{Ethical Approval}

Informed consent was taken from each patient. The research protocol was approved by the Ethical Committee of Faculty of Medicine, Mansoura University (proposal code: R. 17.10.44).

\section{Results}

Characteristics of the age and sex of the studied groups was illustrated in table (1).

Table (1): Characteristics of the age and sex of the studied groups.

\begin{tabular}{|c|c|c|c|c|}
\hline & $\begin{array}{c}\text { Control group } \\
(n .=30)\end{array}$ & $\begin{array}{c}\text { Cirrhosis group } \\
(n .=25)\end{array}$ & $\begin{array}{c}\text { HCC group } \\
(n .=45)\end{array}$ & p value \\
\hline Female / Male & $17 / 13$ & $11 / 14$ & $8 / 37$ & $\begin{array}{c}\text { Chi-square }=12.74 \\
\mathrm{p}<0.001^{*}\end{array}$ \\
\hline $\begin{array}{c}\text { Age (y) } \\
(\text { mean } \pm \text { SD) }\end{array}$ & $50.30 \pm 6.31$ & $58.04 \pm 8.53$ & $55.98 \pm 7.59$ & $\begin{array}{c}\text { ANOVA }=15.92 \\
\mathrm{p}<0.0001^{*}\end{array}$ \\
\hline
\end{tabular}

*Significant, $\mathrm{n}=$ number, SD: standard deviation.

In tables (2) and (3), laboratory tests and radiological findings confirmed the diagnosis of chronic decompensated liver conditions. In cirrhosis and HCC groups, most of patients included in this study had decompensated liver disease, being given a Child-Pugh classification grade $C$ (9 in cirrhotic and 21 in
HCC groups). Condition of the spleen mostly was enlarged in 11 and 36 cases in cirrhotic and HCC groups respectively. Regarding presence of ascites, the majority in cirrhotic group was suffering from marked ascites (14 cases) while the majority in HCC groups was no ascites (23 cases). 
Table (2): Laboratory tests in the studied groups.

\begin{tabular}{|c|c|c|c|}
\hline $\begin{array}{c}\text { Variables } \\
\text { (Mean } \pm \text { SD) }\end{array}$ & $\begin{array}{c}\text { Control group } \\
(n .=30)\end{array}$ & $\begin{array}{c}\text { Cirrhosis group } \\
\quad(n .=25)\end{array}$ & $\begin{array}{c}\text { HCC group } \\
\quad(n .=45)\end{array}$ \\
\hline \multirow{3}{*}{$\begin{array}{l}\text { ALT (U/L) } \\
\text { p1 } \\
\text { p } 2\end{array}$} & $28.27 \pm 4.799$ & $64.60 \pm 77.236$ & $52.40 \pm 21.366$ \\
\hline & & $0.005^{*}$ & $0.043^{*}$ \\
\hline & & & 0.711 \\
\hline \multirow{3}{*}{$\begin{array}{l}\text { AST (U/L) } \\
\text { p } 1 \\
\text { p } 2\end{array}$} & $37.50 \pm 56.327$ & $72.92 \pm 38.746$ & $62.00 \pm 23.472$ \\
\hline & & $0.004 *$ & $0.030^{*}$ \\
\hline & & & 0.816 \\
\hline \multirow{3}{*}{$\begin{array}{l}\text { INR } \\
\text { p } 1 \\
\text { p } 2\end{array}$} & $1.19 \pm .145$ & $1.40 \pm .344$ & $1.29 \pm .186$ \\
\hline & & $0.003^{*}$ & 0.227 \\
\hline & & & 0.159 \\
\hline \multirow{3}{*}{$\begin{array}{l}\operatorname{Albumin}(\mathbf{g} / \mathbf{d L}) \\
\mathrm{p} 1 \\
\mathrm{p} 2\end{array}$} & $3.89 \pm .505$ & $2.30 \pm .590$ & $3.06 \pm .616$ \\
\hline & & $0.001 *$ & $0.001 *$ \\
\hline & & & $0.001 *$ \\
\hline \multirow{3}{*}{$\begin{array}{l}\text { Bilirubin (mg/dL) } \\
\text { p } 1 \\
\text { p } 2\end{array}$} & $0.82 \pm .110$ & $5.64 \pm 6.271$ & $1.72 \pm .945$ \\
\hline & & $0.001 *$ & 0.691 \\
\hline & & & $0.001 *$ \\
\hline \multirow{3}{*}{$\begin{array}{l}\text { Alpha-Fetoprotein }(\mathbf{n g} / \mathbf{m l}) \\
\text { p1 } \\
\text { p2 }\end{array}$} & $8.1 \pm 3.4$ & $10.7 \pm 10.4$ & $104.1 \pm 114.9$ \\
\hline & & $<0.0001^{*}$ & $<0.0001^{*}$ \\
\hline & & & $<0.001^{*}$ \\
\hline
\end{tabular}

*Significant. $\mathrm{n}=$ number. HCC: Hepatocellular carcinoma. $\mathrm{p} 1$ : difference between both cirrhotic and HCC groups and control group.p2: difference between cirrhotic and HCC groups.INR: International normalized ratio, ALT: Alanine aminotransferase, AST: Aspartate aminotransferase. 
Table (3): Radiological findings of the liver, spleen, presence of ascites and Child-Pugh classification in cirrhosis and HCC groups.

\begin{tabular}{|c|c|c|c|}
\hline & $\begin{array}{c}\text { Cirrhosis group } \\
(n .=25)\end{array}$ & $\begin{array}{c}\text { HCC group } \\
(n .=45)\end{array}$ & $\begin{array}{c}\text { Chi- square } \\
p \text { value }\end{array}$ \\
\hline \multicolumn{4}{|l|}{ Liver } \\
\hline Average coarse & 2 & & 10.83 \\
\hline Early cirrhotic & 4 & & $\mathrm{p}<0.001^{*}$ \\
\hline Shrunken cirrhotic & 19 & 45 & \\
\hline \multicolumn{4}{|l|}{ Spleen } \\
\hline Normal & 3 & 1 & \\
\hline Mild enlargement & 4 & 3 & 12.31 \\
\hline Moderate enlargement & 7 & 5 & $p<0.001 *$ \\
\hline Marked enlargement & 11 & 36 & \\
\hline \multicolumn{4}{|l|}{ Ascites } \\
\hline No ascites & 2 & 23 & 12.15 \\
\hline Mild & 2 & 8 & $\mathrm{p}<0.001^{*}$ \\
\hline Moderate & 7 & 4 & \\
\hline Marked & 14 & 10 & \\
\hline \multicolumn{4}{|l|}{ Child-Pugh classification } \\
\hline $\mathrm{A}$ & 8 & 10 & 20.0 \\
\hline $\mathrm{B}$ & 8 & 14 & $\mathrm{p}<0.001 *$ \\
\hline $\mathrm{C}$ & 9 & 21 & \\
\hline
\end{tabular}

* Significant.n=number.HCC: Hepatocellular carcinoma

groups separately (Table 4). There were significant increase in zinc level and significant decrease in magnesium and copper levels in comparison between $\mathrm{HCC}$ and cirrhotic groups.
Copper level showed significantly $(p<0.001)$ increased values in cirrhosis and HCC groups in comparison to the control group while magnesium and zinc were significantly $(p<0.001)$ decreased comparing to control group in both cirrhosis and HCC 
Table (4):Levels of zinc, magnesium and copper in the studied groups.

\begin{tabular}{|l|c|c|c|}
\hline \multicolumn{1}{|c|}{$\begin{array}{c}\text { Variables } \\
\text { (Mean } \pm \text { SD) }\end{array}$} & $\begin{array}{c}\text { Control group } \\
(n .=30)\end{array}$ & $\begin{array}{c}\text { Cirrhosis group } \\
(n .=25)\end{array}$ & $\begin{array}{c}\text { HCC group } \\
(n .=45)\end{array}$ \\
\hline \multirow{2}{*}{$\begin{array}{l}\text { Zinc (ug/dL) } \\
\text { p 1 } \\
\text { p 2 }\end{array}$} & $8.62 \pm 2.89$ & $5.18 \pm 2.55$ & $6.25 \pm 3.25$ \\
\hline \multirow{2}{*}{$\begin{array}{l}\text { Magnesium (ug/dL) } \\
\text { p 1 } \\
\text { p 2 }\end{array}$} & & $<0.001^{*}$ & $<0.001^{*}$ \\
\hline \multirow{2}{*}{$\begin{array}{l}\text { Copper (ug/dL) } \\
\text { p 1 } \\
\text { p 2 }\end{array}$} & $3.49 \pm 0.37$ & $1.87 \pm 0.33$ & $<0.001^{*}$ \\
\cline { 2 - 4 } & & $<0.001^{*}$ & $<.48 \pm 0.39$ \\
\cline { 2 - 4 } & $106.98 \pm 2.15$ & $206.28 \pm 8.48$ & $<0.001^{*}$ \\
\cline { 2 - 4 } & & $<0.001^{*}$ & $<0.001^{*}$ \\
\cline { 2 - 4 } & & & $<0.65 \pm 3.87$ \\
\hline
\end{tabular}

*Significant. $\mathrm{n}=$ number. $p 1$ : difference between both cirrhotic and HCC groups and control group. p1: difference between cirrhotic and HCC groups. HCC: Hepatocellular carcinoma

There was a significant negative correlation between zinc levels and levels of AST, ALT, INR, albumin and bilirubin meanwhile; there was a significant positive correlation between levels of copper and the same parameters. As regards the magnesium levels, it had non- significant positive correlation with the same parameters (Table $5)$.

Table (5): The correlation between the studied metals (zinc, magnesium and copper) and levels of ALT, AST, INR, albumin, bilirubin and creatinine in the cirrhosis and HCC groups.

\begin{tabular}{|c|c|c|c|c|c|c|c|c|c|}
\hline & & Zinc & Magnesium & Copper & ALT & AST & INR & Albumin & Bilirubin \\
\hline \multirow{2}{*}{ Zinc } & $\begin{array}{l}\text { Pearson } \\
\text { Correlation }\end{array}$ & 1 & $-0.399^{* *}$ & $-0.803^{* *}$ & -0.162 & -0.214 & $-0.238^{*}$ & $0.423^{* *}$ & $-0.444^{* *}$ \\
\hline & $\mathrm{p}$ value & & 0.001 & 0.001 & 0.181 & 0.075 & 0.047 & 0.001 & 0.001 \\
\hline \multirow{2}{*}{ Magnesium } & $\begin{array}{l}\text { Pearson } \\
\text { Correlation }\end{array}$ & $-0.399^{* *}$ & 1 & $.465^{* *}$ & 0.019 & 0.008 & 0.144 & -0.207 & 0.128 \\
\hline & $p$ value & 0.001 & & 0.001 & 0.876 & 0.946 & 0.233 & 0.091 & 0.295 \\
\hline \multirow[t]{2}{*}{ Copper } & $\begin{array}{l}\text { Pearson } \\
\text { Correlation }\end{array}$ & $-0.803^{* *}$ & $0.465^{* *}$ & 1 & 0.079 & 0.150 & 0.215 & $-0.519^{* *}$ & $0.455^{* *}$ \\
\hline & $\mathrm{p}$ value & 0.001 & 0.001 & & 0.514 & 0.215 & .074 & 0.001 & 0.001 \\
\hline
\end{tabular}

*Significant. INR: International normalized ratio, ALT: Alanine aminotransferase, AST: Aspartate aminotransferase. 
Regarding the correlations between the studied trace metals, there was a significant negative correlation between zinc and magnesium, zinc and copper while; there was a significant positive correlation between copper and magnesium (Figure 1[A, B \&C]).
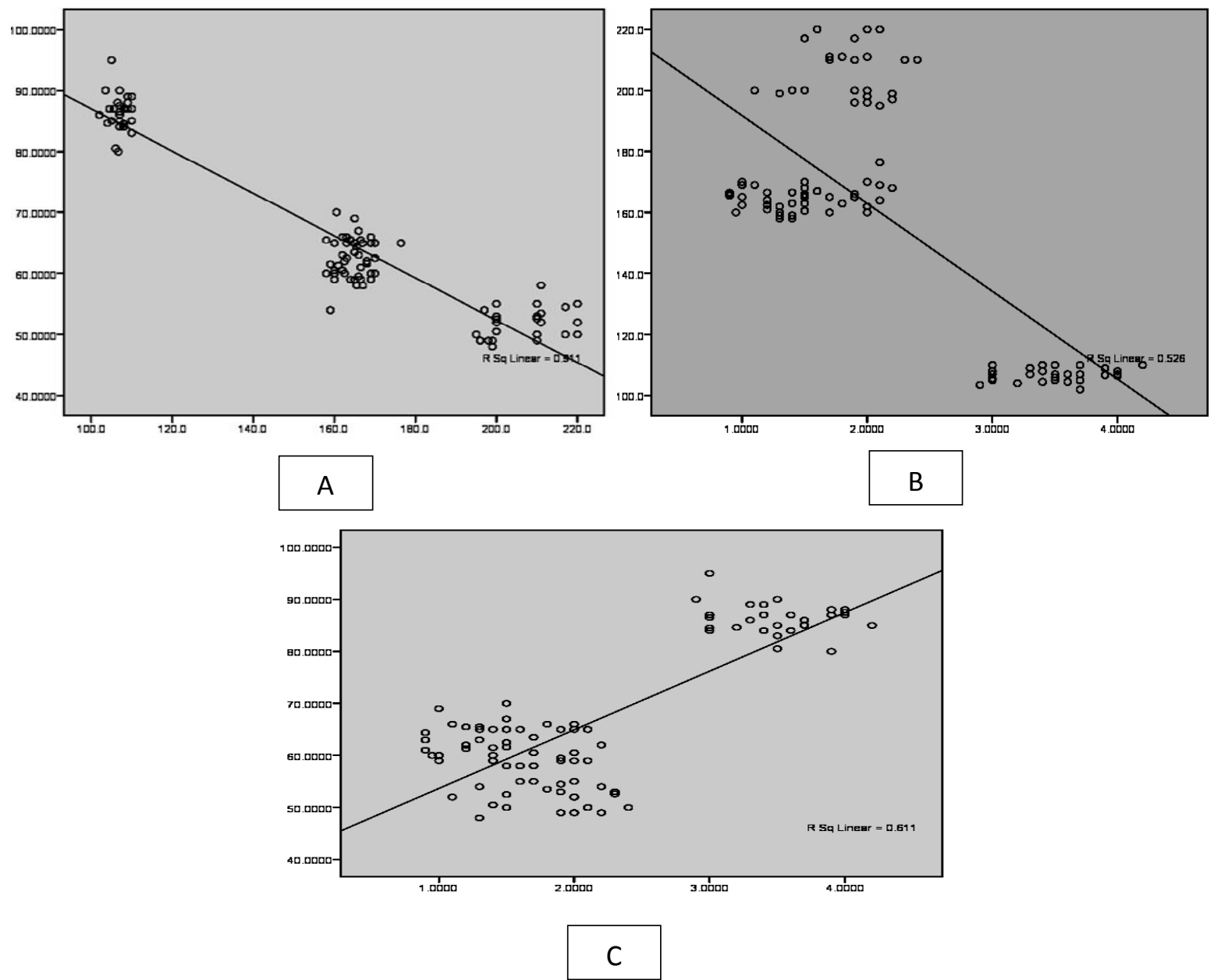

Fig. (1): Correlation between the studied metals: (A): zinc and copper. (B): zinc and magnesium. (C): copper and magnesium in the cirrhosis and HCC groups.

Table (6) showed a significant negative correlation between zinc and magnesium levels and the advances in liver condition (shrunken cirrhotic), advances in spleen condition (marked enlarged) and presence of ascites was observed, while there is nonsignificant negative correlation between ChildPugh classification and the levels of zinc and magnesium in cirrhosis and HCC groups. As regards copper level, there was a significant positive correlation between the copper level and the advances in liver condition (shrunken cirrhotic), advances in spleen condition (marked enlarged), presence of ascites and Child-Pugh classification. 
Table (6): The correlation between the studied metals and condition of the liver, spleen, presence of ascites and child-pugh classification in the cirrhosis and HCC groups.

\begin{tabular}{|l|l|c|c|c|c|}
\hline \multicolumn{2}{|l|}{} & $\begin{array}{c}\text { Advances in } \\
\text { liver } \\
\text { condition }\end{array}$ & $\begin{array}{c}\text { Advances in } \\
\text { spleen } \\
\text { condition }\end{array}$ & $\begin{array}{c}\text { Presence of } \\
\text { ascites }\end{array}$ & $\begin{array}{c}\text { Child-pugh } \\
\text { classification }\end{array}$ \\
\hline \multirow{3}{*}{ Zinc } & Correlation Coefficient & $-0.460^{*}$ & $-0.249^{*}$ & $-0.460^{*}$ & -0.096 \\
\cline { 2 - 6 } & $p$ value & 0.001 & 0.001 & 0.001 & 0.313 \\
\hline \multirow{3}{*}{ Magnesium } & Correlation Coefficient & $-0.566^{*}$ & $-0.603^{*}$ & $-0.153^{*}$ & 0.015 \\
\cline { 2 - 7 } & $p$ value & 0.001 & 0.001 & 0.04 & 0.879 \\
\hline \multirow{2}{*}{ Copper } & Correlation Coefficient & 1.000 & $0.443^{*}$ & $0.221^{*}$ & $0.386^{*}$ \\
\cline { 2 - 7 } & $p$ value & & 0.001 & 0.004 & 0.001 \\
\hline
\end{tabular}

* Significant.

Figures (2) and (3) showed the levels of the studied metals in relation to Child-Pugh classification in cirrhosis and HCC groups.
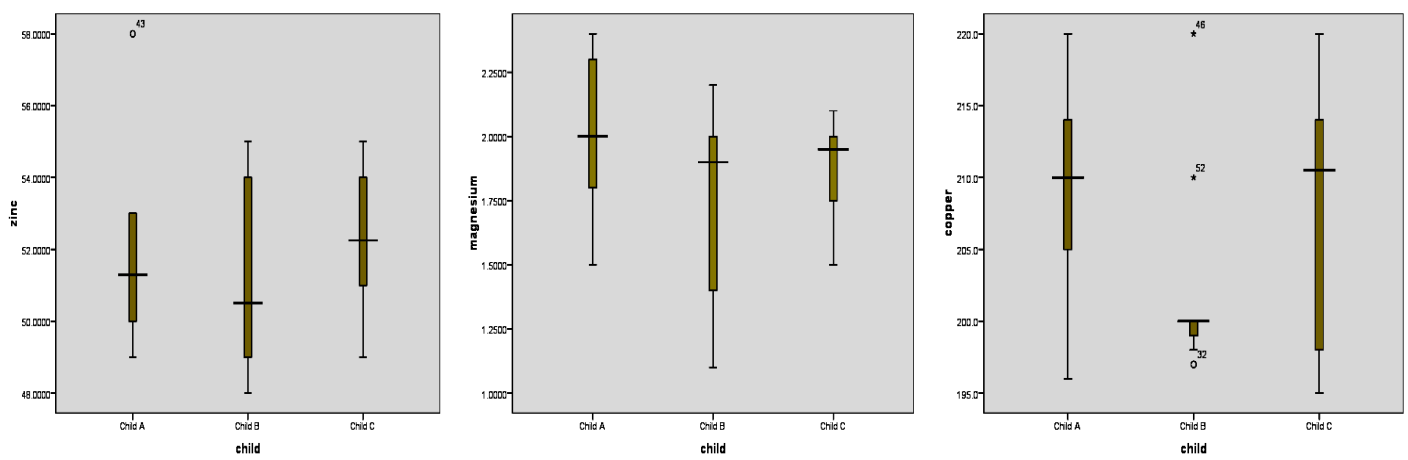

Fig. (2): Box plot of the levels of studied metals in relation to Child-Pugh classification in the cirrhosis group 

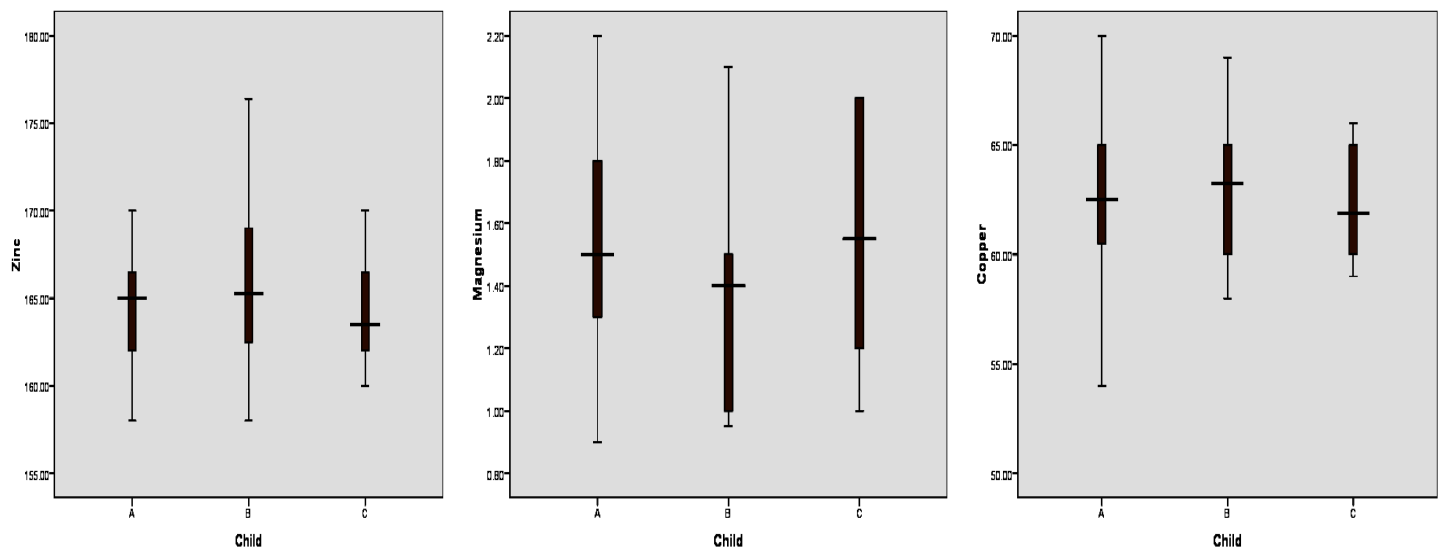

Fig. (3): Box plot of the levels of studied metals in relation to Child-Pugh classification in the HCC group

\section{Discussion}

Trace elements may be involved in the pathogenesis of liver disease.They may produce direct hepatic toxicity or impaired liver function via decrease in their levels (Loguercio et al., 2001).Reactive copper may stimulate Kupffer cell's leading to direct or indirect liver damage (Rahelic et al., 2006). Magnesium may be depleted in cirrhosis but there are not enough evidences on that. Patients with liver cirrhosis showed considerably reduced muscle strength and muscle magnesium so it may have a role in hepatic encephalopathy and muscle cramps (Meir Medical Center, 2013). Many researchers still study the possible connection of zinc, copper, and magnesium in pathogenesis of chronic liver diseases and its progress (Agarwal et al., 2017).

Because of the high prevalence of hepatic diseases in Egypt, the effect of these metals should be known and well-studied to take scientific steps for prophylaxis and avoidance of disease deterioration. So the current work was designed to estimate the level of copper, magnesium and zinc in patients of cirrhosis and hepatocellular carcinoma (HCC) to determine their correlation to pathogenesis of these diseases.
In the current study, copper level showed significantly increased values in cirrhosis and HCC groups while magnesium and zinc were significantly decreased comparing to control group. There were significant increase in zinc level and significant decrease in magnesium and copper levels in HCC group compared to cirrhotic group.

Many studies have demonstrated a marked decrease in zinc levels in HCC tissue compared with normal liver tissue (Kawata et al., 2006 and Al-Ebraheem et al., 2009). On the other hand Ebara et al. (1999) had reported a zinc increase in HCC, which was subsequently reversed in researches by the same research group (Ebara et al., 2000; Kawata et al., 2006). They confirmed decrease in zinc in HCC. In addition, Franklin et al. (2012) recorded association between the decreased levels of zinc in HCC and the degree of advancing malignancy. Lin et al. (2006) also implied that the mean zinc level in the hepatic cirrhotic patients was significantly lower than controls. This finding is in agreement with the observation reported by Grüngreiff (2002).

In accordance with our results, Qasim et al. (2010) found that serum copper level was significantly higher, while the serum zinc level was significantly lower in cirrhotic patients than healthy control groups. 
On the other hand, Cesur et al. (2005) did not find any statistically significant difference between healthy control and patients with cirrhosis as regards serum zinc and copper concentrations.Therefore, in attempt to explain the decreased zinc levels, Costello and Franklin (2014) stated that the malignant cells are developing certain mechanisms to decrease the cellular accumulation of zinc to levels that are not cytotoxic, but still support their development, growth, proliferation, and malignant activities. For example, HCC tissue tries to decrease zinc levels in hepatoma cells by alteration of expression and abundance of zinc transporters.

On a similar scale, a significant negative correlation between zinc levels and levels of AST, ALT, INR, albumin and bilirubin were observed meanwhile; there was a significant positive correlation between levels of copper and the same parameters. As regards the magnesium levels, it had nonsignificant positive correlation with the same parameters and this proves the direct correlation between the levels of these trace element and the changes in liver function parameters.

In accordance, Takashiet al. (2007) indicated significant correlations between serum zinc level and AST and albumin. Accordingly, Omran et al. (2017) found that serum zinc level had a negative significant correlation with INR but in disagreement with our results they found no correlation between zinc level and bilirubin, ALT, AST, or albumin. On the other hand a study done by Anber et al. (2016) found non-significant correlations between serum zinc, AST and albumin.

In the current study, regarding the correlations between the studied trace metals, there was a significant negative correlation between zinc and magnesium, zinc and copper while; there was a significant positive correlation between copper and magnesium. In agreement with our results, Agarwal et al. (2017) found a significant negative correlation between zinc and copper, as well as between copper and magnesium.

A significant negative correlation was observed in the current study between zinc and magnesium levels and the advances in liver condition (shrunken cirrhotic), advances in spleen condition (marked enlarged) and presence of ascites, while there is non-significant negative correlation between Child-Pugh classification and the levels of zinc and magnesium in cirrhosis and HCC groups. As regards copper level, there was a significant positive correlation between the copper level and the advances in liver condition (shrunken cirrhotic), advances in spleen condition (marked enlarged), presence of ascites and Child-Pugh classification.

In compatible with our results, Agarwal et al. (2017) observed that the serum copper was significantly increased with advancement of liver disease. These findings are in agreement with the study done by Somi et al. (2007) who found that zinc level was significantly lower in Child's Class B than Child's Class A. Also, Yoshida et al. (2001) found that zinc level was significantly lower in patients with decompensated liver cirrhosis than patients with compensated cirrhosis. In accordance, Rahelic et al. (2006) stated that the copper concentration increased in advanced liver maladies, as it is responsible for production of the toxic hydroxyl radicals. Kar et al. (2014) explained the possible causes of increased copper level by increased its uptake from the gut, diminished excretion by the liver, and tissue breakdown with consequent release of copper stores.

In agreement to our results, Nangliya et al. (2015) as they found increased concentration of copper with severity of liver disease while, 
serum zinc, magnesium levels were significantly decreased with advancement of liver disease as compared to early stage of liver cirrhosis. They showed a significant negative correlation with Child-Pugh Score. While, Prystupa et al. (2016) found that serum concentrations of copper were significantly lower in patients with liver cirrhosis compared to controls. On the other hand, Rahelic et al. (2006) observed no significant changes in magnesium levels between liver cirrhosis patients and control healthy group. Kar et al. (2014) also suggested that magnesium levels are not depending on the degree of severity of liver diseases.

\section{Conclusion}

There is association between copper, magnesium and zinc and the severity of the cirrhosis and HCC. Further studies are needed to determine effects of supplementation of zinc and magnesium on the clinical course of liver cirrhosis and HCC.

\section{References}

Abe, A.; Yamashita, S. and Noma, A.(1989): "Sensitive, direct colorimetric assay for copper in serum". Orient. Pharm. Exp. Med., 35(4):552-554.

Agarwal, A.; Avarebeel, S.; Choudhary, N.S.; et al. (2017): "Correlation of trace elements in patients of chronic liver disease with respect to ChildTurcotte- Pugh scoring system". Journal of Clinical and Diagnostic Research, 11(9): OC25-OC28.
Al-Ebraheem, A.; Farquharson, M.J. and Ryan, E.(2009): "The evaluation of biologically important trace metals in liver, kidney and breast tissue". Appl. Radiat. Isot., 67: 470-474.

Arain, S.A.; Afridi, H.I.; Kazi, J.G.; et al. (2013): "Investigation of alteration in the levels of iron and copper in scalp hair samples of patients having different types of viral hepatitis". Biological Trace Element Research, $156(1-3)$ : $5-11$.

Cesur, S. A.; Cebeci, G.O.; Kavas, N.; Yilmaz, D.I. and Buyukkagnici, J. (2005): "Serum copper and zinc concentrations in patients with chronic hepatitis C". Journal of Infect., 51 (1) 3537.

Chen, J. and Teo, K.C. (2001): "Determination of cadmium, copper, lead and zinc in water samples by flame atomic absorption spectrometry after cloud point extraction". Anal.Chim.Acta., 450: 215-222.

Cholongitas, E.; Papatheodoridis, G.V.; Vangeli, M.; et al. (2005): "Systematic review: The model for end-stage liver disease--should it replace Child-Pugh's classification for assessing prognosis in cirrhosis?" Alimentary Pharmacology \& Therapeutics, 22 (11-12): 1079-1089.

Costello, L.C. and Franklin, R.B. (2014): "The status of zinc in the development of hepatocellular cancer; an important, but neglected, clinically established relationship". Cancer Biol. Ther., 15(4): 353-360.

Ebara, M.; Fukuda, H.; Hatano, R.; et al. (2000):"Relationship between copper, zinc and metallothionein in hepatocellular carcinoma and its surrounding liver parenchyma". J. Hepatol., 33: 415-422.

Franklin, R.B.; Levy, B.A.; Zou, J.; et al. (2012): $\quad$ ZIP14 zinc transporter 
downregulation and zinc depletion in the development and progression of hepatocellular cancer". J. Gastrointest. Cancer, 43: 249-257.

Grüngreiff, K. (2002): " Zinc in liver disease". J. Trace Elem. Exp. Med., 15: 67-78.

Grüngreiff, K. and Reinhold, D. (2011): Zinc and Liver. In: Zinc in Human Health. Rink, L. (Ed.) 1st ed. Amsterdam: IOS Press, P.P. 473-492.

Hiroyuki, F.; Masaaki, E.; Hiroyuki, Y.; et al. (2004):"Trace elements and cancer". J.M.A.J., 47(8): 391-395.

https:/clinicaltrials.gov/ct2/show/NCT0 1894867

Kar, K.; Dasgupta, A.; Bhaskar, M. and Sudhakar, K. (2014): "Alteration of micronutrient status in compensated and decompensated liver cirrhosis". Indian J. Clin. Biochem., 29 (2): 232-237.

Kawata, T.; Nakamura, S.; Nakayama, A.; et al. (2006): "An improved diagnostic method for chronic hepatic disorder: analyses of metallothionein isoforms and trace metals in the liver of patients with hepatocellular carcinoma as determined by capillary zone electrophoresis and inductively coupled plasma-mass spectrometry". Biol. Pharm. Bull., 29:403-409.

Khayam-Bashi, H.; Liu, T.Z. and Walter, V.(1977): "Measurement of serum magnesium with a centrifugal analyzer". Clin. Chem., 23: 289-291.

Lin, C.C.; Huang, J.F.; Tsai, L.Y. and Huang, Y. L. (2006): "Selenium, iron, copper, and zinc levels and copper-tozinc ratios in serum of patients at different stages of viral hepatic diseases". Biol. Trace Elem. Res., 109:15-23.
Loguercio, C.; De Girolamo, V.; Federico, A.; et al. (2001): "Relationship of blood trace elements to liver damage, Nutritional status, and oxidative stress in chronic nonalcoholic liver disease". Biological Trace Element Research, 81 (3): 245-254.

Matsui, T. (2012): "Magnesium and liver". Clin. Calcium, 22(8): 1181-7. doi: CliCa 120811811187. Abstract.

Meir Medical Center (2013): Magnesium deficiency in cirrhotic patients. Clinical Trials.gov Identifier: NCT01894867.

Meng, Z. and Zhang, Q. (2006): "Oxidative damage of dust storm fine particles instillation on lungs, hearts and livers of rats". Environ. Toxicol. Pharmacol., 22: 277-282.

Nangliya, V.; Sharma, A.; Yadav, D.; et al. (2015): "Study of trace elements in liver cirrhosis patients and their role in prognosis of disease". Biol. Trace Elem. Res., 165(1): 35-40.

Omran, D. A. ; Darweesh, S.K.; Fouad, H.; et al. (2017): " Serum zinc deficiency and its relation to liver fibrosis in chronic HCV: a real-life Egyptian study". Biol. Trace Elem. Res., 179(1):1-7.

Prystupa, A.; Blażewicz, A.; Kiciński, P.; et al. (2016): "Serum concentrations of selected heavy metals in patients with alcoholic liver cirrhosis from the Lublin region in eastern Poland". Int. J. Environ. Res. Public Health, 13(6): 582-585.

Qasim, R.; Saniullah, S.; Muzaffar, A.S.; et al. (2010): "Serum copper and zinc concentration in patients with chronic hepatitis C". Medicine, 16 (1): 27-30.

Qasim, R.; Saniullah, S.; Muzaffar, A.S.; et al. (2010): "Serum copper and zinc 
concentration in patients with chronic hepatitis C". Medicine, 16 (1), 27-30

Rahelic, D.; Kujundzic, M.; Romic, Z.; et al. (2006): "Serum concentration of zinc, copper, manganese and magnesium in patients with liver cirrhosis". Coll. Antropol., 30: 523-528.

Somi, M.; Rahimi, A.O.; Moshrefi, B. and Maghami, J. G. (2007): "Nutritional status and blood trace elements in cirrhotic patients". Hep. Mon., 7(1):2732.
Takashi, M.; Saito, H. and Higashimoto, M. (2007): "Possible inhibitory effect of oral zinc supplementation on hepatic fibrosis through down regulation of TIMP-1". Hepatol. Res.,37(6):405 - 409.

Yoshida, Y.; Higashi, T.; Nouso, K.; et al. (2001): "Effect of zinc deficiency/zinc supplementation on ammonia metabolism in patients with decompensated liver cirrhosis". Acta. Med. Okayama, 55:349455. 


\section{دور النحاس والماغنسيوم والزنكك في طريقة تطور مرض سرطان الخلايا الكبدية والتليف الكبدي}

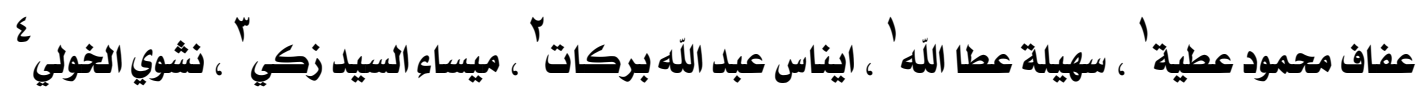

'قتم الطب الشرعي والسموم الإكلينيكية ـ كلية الطب - جامعة المنصورة

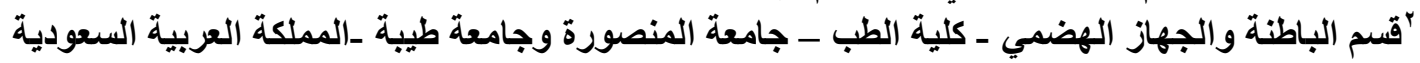

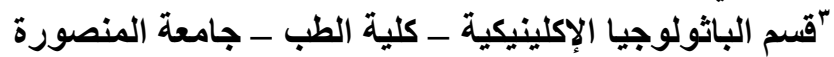

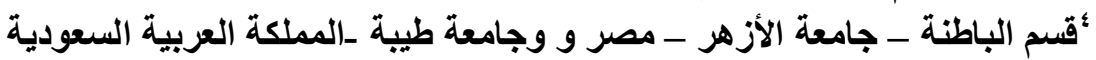

تهذف هذه الدر اسـة إلى الكشف عن مستوى بعض العناصـر النـادرة (النحساس والماغنسيوم و الزنك) في المرضى الذين يعانون من تليف الكبد والسرطان الكبدي لكي نحدد العلاقة بينهم وبين التسبب في هذه الأمر اض.

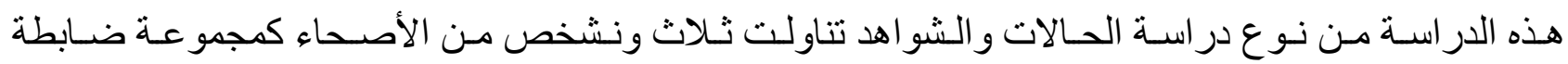

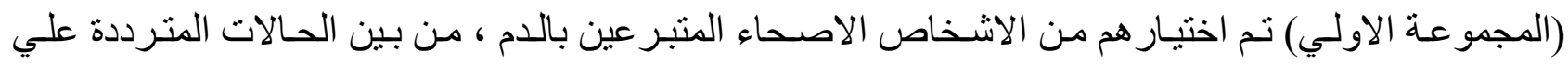

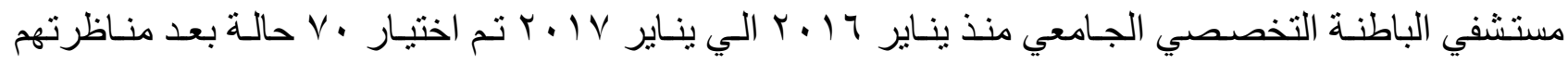
اكلينيكي او عمل الفحوصات و الأشعات الضرورية وتم تصنيفهم الي: المجمو عة الثانية: خمسة و عشرون مريضًا

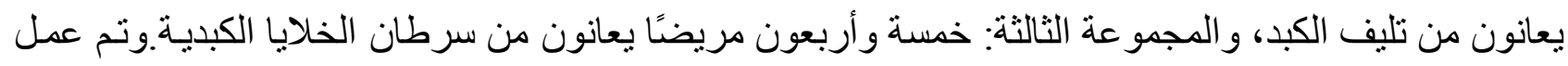

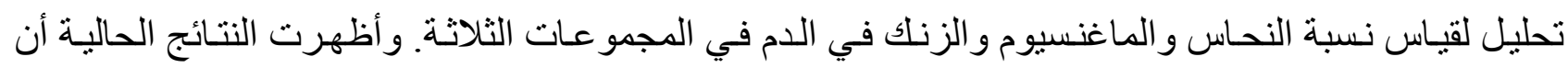

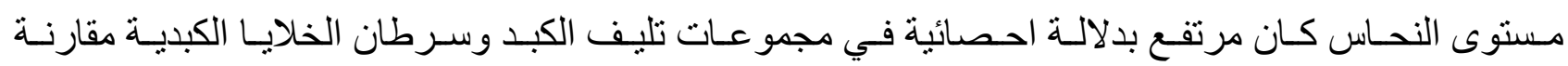
بالمجمو عة الضابطة بينما كان مستوي الماغنيسيوم و الزنلك منخفض بدلالة احصائية عن المجمو عة الضابطة في

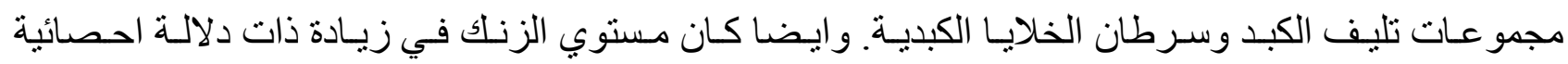

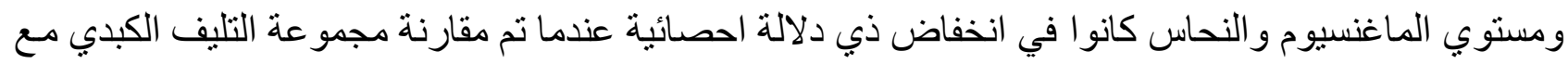
مجمو عة السرطان الكبدي.وكان هناك ارتباط سلبي بين مستويات الزنك و الماغنيسيوم بشكل منفصل مـع تطور الحالة المرضية للكبد و الطحال ووجود الاستسقاء وتصنيف تشايلد- بوغ في مجمو عات تليف الكبد وسرطان الخلايا الكبدية. وفيما يتعلق بمستوى النحاس فقد كان هنالك ارتباط إيجابي بين مستوى النحاس وتطور الحالة

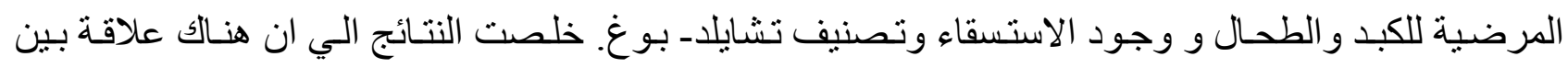
النحاس و الماغنيسيوم و الزنلك ودرجة التقدم في الحالة المرضية لتليف الكبد و السرطان الكبدي. 